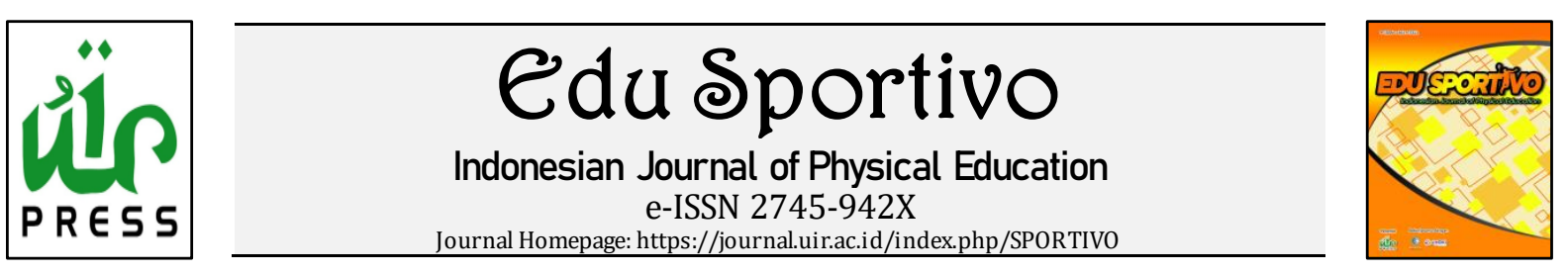

\title{
Analisis perkuliahan daring mahasiswa PJKR Universitas PGRI Semarang sebagai dampak pandemi covid 19
}

\section{Analysis of online learning students of PJKR University PGRI Semarang as the impact of covid pandemics 19}

\author{
1Setiyawan, ${ }^{2}$ Pandu Kresnapati, ${ }^{* 3}$ Danang Aji Setiawan \\ 1,2,*3 Pendidikan Jasmani Kesehatan dan Rekreasi, Universitas PGRI Semarang, Semarang, Indonesia
}

Received: 17 June 2020; Accepted 04 August 2020; Published 08 August 2020

OPEN $\odot$ ACCESS

\begin{abstract}
ABSTRAK
Tujuan dalam melakukan penelitian ini adalah mendapatkan data bentuk perkuliahan dan hasil informasi upaya mahasiswa dalam mengikuti perkuliahan online pada mahasiswa PJKR Universitas PGRI Semarang sebagai dampak covid 19. Metode penelitian ini menggunakan deskriptif kuantitatif dengan menggunakan metode survei. Teknik pengumpulan data menggunakan kuesioner. Subjek dalam penelitian ini adalah mahasiswa PJKR Universitas PGRI Semarang semester dua, empat, dan enam. Penelitian yang dilakukan memperoleh hasil sebagai berikut: (a) Aspek distribusi siswa semester dua 47,7\%, semester empat $21,2 \%$ dan semester enam 31,1\%. (b) Aspek Aplikasi yang paling banyak digunakan adalah Zoom 34,7\%, SIP 41,2\%, SPADA $1,3 \%$ dan Google Classroom 22,8\%. (c) Durasi pembelajaran online yaitu lebih dari 60 menit 18,6\%, 30 menit hingga 60 menit $64,8 \%$ dan di bawah 30 menit $16,6 \%$. (d) Aspek material, yaitu: mudah dipahami $71,2 \%$ dan materi sulit dipahami 28,8\%. (e) Aspek kesiapan siswa, dalam kategori siap 20,9\%, cukup siap 52,4\%, kurang siap 26,7\%. (f) Hambatan terbesar bagi siswa adalah menantang sinyal $58,9 \%$, kuota $25,3 \%$, dan waktu 15,8\%. Dari penelitian yang telah dilakukan dapat disimpulkan: (1) Bentuk perkuliahan yang dilakukan di Program Studi PJKR Universitas PGRI Semarang memanfaatkan platform pembelajaran online seperti Zoom, Google Clasroom, SPADA, maupun SIP. Sedangkan untuk perkuliahan praktek lapangan menggunakan bentuk video dan penugasan, (2) Upaya mahasiswa dalam mengikuti pembelajaran online cukup baik dengan perolehan cukup siap dan persentasenya $52.4 \%$.
\end{abstract}

Kata Kunci: Analisis; Daring; Pandemi; Covid-19

*Corresponding Author

Email: danangpjkrupgris@gmail.com

\section{ABSTRACT}

The purpose of conducting this research is to obtain data on the form of lectures and the results of information on students' efforts to take part in online lectures on PJKR students at the University of PGRI Semarang as a covid effect 19. The research method uses quantitative descriptive using survey methods. Data collection techniques using a questionnaire. The subjects in this study were PJKR University PGRI Semarang students in the second, fourth and sixth semesters. Research conducted obtained the following results: (a) Aspects of the distribution of students in the second semester $47.7 \%$, semester four $21.2 \%$ and semester six $31.1 \%$. (b) The most widely used application aspects are Zoom $34.7 \%$, SIP $41.2 \%$, SPADA $1.3 \%$ and Google Classroom 22.8\%. (c) The duration of online learning is more than 60 minutes $18.6 \%, 30$ minutes to 60 minutes $64.8 \%$ and under 30 minutes $16.6 \%$. (d) Material aspects, namely: easy to understand $71.2 \%$ and material difficult to understand $28.8 \%$. (e) Aspects of student readiness, in the ready category of $20.9 \%$, quite ready $52.4 \%$, less ready $26.7 \%$. (f) The biggest obstacle for students is challenging the signal of $58.9 \%$, quota of $25.3 \%$, and time of $15.8 \%$. From the research that has been carried out it can be concluded: (1) The form of lectures conducted at the PJKR Study Program of the University of PGRI Semarang utilizes online learning platforms such as Zoom, Google Classroom, SPADA, and SIP. While for field practice lectures using video and assignment forms, (2) The efforts of students to take part in online learning are quite good with the acquisition being quite ready and the percentage is $52.4 \%$.

Keywords: Analysis; Online; Pandemic; Covid-19

Copyright (C) 2020

Edu Sportivo: Indonesian Journal of Physical Education

\section{https://doi.org/10.25299/es:ijope.2020.vol1(1).5148}

How To Cite: Setiyawan., Kresnapati, P., \& Setiawan, D. A. (2020). Analisis perkuliahan daring mahasiswa PJKR Universitas PGRI Semarang sebagai dampak pandemi covid 19. Edu Sportivo: Indonesian Journal of Physical Education, 1(1), 25-32. https://doi.org/10.25299/es:ijop e.2020.vol1(1).5148. 


\section{PENDAHULUAN}

Olahraga mempunyai peran penting dalam kehidupan manusia. Pada saat sekarang ini olahraga sudah menjadi sebuah kebutuhan bagi sebagian orang, banyak orang mengkhusukan waktunya untuk kegiatan olahraga, baik pagi, sore bahkan malam hari (Cendra \& Gazali, 2019). Dalam kehidupan kata pendidikan merupakan istilah yang sudah tidak asing lagi bagi masyarakat umum dengan konteks pemahamanyang bervariasi, dari yang abstrak sampai dengan yang kongkrit praktis. Pendidikan berasal dari kata "didik", lalu kata ini mendapat awalan "me" sehingga menjadi "mendidik" artinya, memelihara dan memberi latihan. Dalam memelihara dan memberi latihan diperlukan adanya ajaran, tuntunan, dan pimpinan mengenai akhlak dan kecerdasan pikiran (Syah, 2010). Dalam Undang-Undang Sistem Pendidikan Nasional No 20 Tahun 2003 disebutkan bahwa pendidikan nasional berfungsi untuk mengembangkan serta membentuk watak peradaban bangsa yang bermartabat untuk mewujudkan cita-cita bangsa, yaitu mencerdaskan kehidupan berbangsa serta berupaya untuk mengembangkan potensi serta kemampuan peserta didik dan menjadikan mereka menjadi manusia yang beriman, berakhlak mulia, berilmu cakap, kreatif, mandiri dan menjadi warga Negara yang demokratis serta tanggung jawab. Seluruh lembaga satuan pendidikan di Indonesia tanpa terkecuali memiliki peran penting untuk merealisasikan fungsi pendidikan nasional tersebut. Semua jenjang pendidikan termasuk sekolah Dasar memiliki peranan penting untuk mewujudkan tujuan pendidikan nasional tersebut (Dalimunthe \& Abdillah, 2015).

Berdasarkan penelitian yang dilakukan oleh Hasanah, Lestari, Rahman, dan Daniel (2020) mengatakan bahwa dilangsir dari website UNESCO yang menyatakan 577 juta pelajar di dunia terancam dengan adanya penyebaran virus corona. Jumlah keseluruhan pelajar yang berpotensi terdampak dari Pandemi ini dari pendidikan pra-sekolah sampai pendidikan menengah atas mencapai 577.305.660. pendidikan tinggipun tidak sedikit yyang terdampak dengan adanya Pandemi ini yang mencapai 86.034.287 pelajar. Pada saat ini seluruh kampus di Indonesia diterapkan kebijakan kegiatan pembelajaran daring dari jarak jauh atau kuliah online.

Lingkungan Perguruan Tinggi dimanapun berada, sedang mengalami perubahan yang sangat cepat, secara global perubahan terlihat dalam bentuk berkembangnya masyarakat informasi yang berbasis ilmu pengetahuan dan teknologi. Dalam situasi yang demikian penguasaan ilmu pengetahuan oleh individu dan atau organisasi akan menjadi prasyarat dan modal dasar bagi upaya pengembangan diri dan organisasi dalam situasi yang makin kompetitif. Dalam masyarakat yang demikian setiap orang dan atau organisasi terpaksa dan dipaksa untuk selalu memperbaharui pengetahuan dan keterampilan jika ingin tetap hidup dan berkembang.

Pada saat ini sistem pendidikan di dunia terganggu oleh adanya wabah Covid-19. Covid-19 merupakan penyakit yang diidentifikasikan penyebabnya adalah virus Corona yang menyerang saluran pernapasan. Penyakit ini pertama kali dideteksi kemunculannya di Wuhan, Tiongkok (Lee \& Hsueh, 2020; Zhu et al., 2020). Sebagaimana diketahui bahwa SARS-Cov-2 bukanlah jenis virus baru. Akan tetapi dalam penjelasan ilmiah suatu virus mampu bermutasi membentuk susunan genetik yang baru, singkatnya virus tersebut tetap satu jenis yang sama dan hanya berganti seragam. Alasan pemberian nama SARS-Cov-2 karena virus corona memiliki hubungan erat secara genetik dengan virus penyebab SARS dan MERS.

Indonesia merupakan salah satu Negara yang terdampak wabah ini memberi kebijakan meliburkan seluruh lembaga pendidikan. Hal ini dilakukan sebagai upaya mencegah penularan virus corona. Akan tetapi pendidikan tidak berhenti begitu saja 
contohnya, saat ini seluruh perguruan tinggi menerapkan kuliah online. Kuliah online dilakukan untuk memberikan kesempatan kepada seluruh warga indonesia untuk menikmati pendidikan dimana saja yang dia suka. Dampak positif kita bisa mendapatkan materi dengan mudah dan belajar mengevaluasi pembelajaran sendiri di rumah sesuai keinginan hati kita masing-masing.

Pandemi Covid-19 telah membuat sistem pembelajaran di kampus dipaksa berubah secara drastis dari pertemuan tatap muka menjadi pembelajaran secara online. Banyak kampus yang belum memiliki infrastruktur pembelajaran online dipaksa melakukan perkuliahan secara daring. Pendidikan di perguruan tinggi tergolong pendidikan yang sangat diminati oleh banyak kalangan masyarakat, dimana masyarakat dapat memilih jurusan atau program studi sesuai dengan kemampuan dan keahlian masing-masing. Dalam perguruan tinggi banyak sekali jurusan-jurusan yang ditawarkan kepada masyarakat seperti halnya jurusan yang berorientasi kepada jurusan Pendidikan maupun non kependidikan. Adapun jurusan yang lebih spesifik yang masuknya ke dalam jurusan yang berupa minat seperti halnya jurusan mesin, jurusan teknologi maupun jurusan dalam bidang kependidikan jasmani olahraga.

Jurusan pendidikan jasmani dan olahraga termasuk dalam program studi di perguruan tinggi yang banyak diminati oleh masyarakat. Selain materi perkuliahan yang dipelajari secara kompek baik teori maupun prakteknya mahasiswa juga beranggapan dengan mereka melanjutkan belajar di jenjang di perguruan tinggi di pendidikan jasmani mahasiswa berharap agar tetap dapat menjaga kesehatan dan kebugarannya, dikarenakan di jurusan pendidikan jasmani memang mahasiswa lebih ditekankan untuk mengikuti perkuliahan dalam bentuk praktek yang harapannya selain dapat menjadikan mahasiswa terampil juga dapat menjaga kesehatan dan kebugaran mahasiswa dengan melakukan aktivitas perkuliahan prakteknya.

Pandemi Covid-19 di Indonesia telah membuat sistem pembelajaran berubah secara drastis dari pembelajaran tatap muka menjadi pembelajaran di rumah secara daring. Sejak munculnya kasus pasien positif Covid-19 di Indonesia, Pemerintah melalui Kementerian Pendidikan dan Kebudayaan dan Kementerian Agama Republik Indonesia., menerapkan kebijakan belajar dan bekerja dari rumah sejak pertengahan Maret 2020. UIN Sunan Gunung Djati Bandung sebagai salah satu PTKIN yang berada di bawah Kementerian Agama, merespon kebijakan tersebut dengan penerapan belajar dan bekerja dari rumah ini melalui surat edaran yang dikeluarkan pada tanggal 15, 26 dan 30 Maret 2020 (Jamaluddin, Ratnasih, Gunawan, \& Paujiah, 2020). Perkuliahan secara daring terpaksa mengubah sistem tatap muka menjadi perkuliahan jarak jauh daring akibat Pendemi Covid19 yang melansa Indonesia di tengah keterbatasan infrastruktur yang ada. Hal ini menyebabkan pembelajaran yang dilakukan menjadi kurang efisien, peserta didik lebih susah memahami materi yang diberikan dosen, kurangnya interaksi antara dosen dan mahasiswa membuat mereka susah memahami materi yang diberikan, mahasiswa lebih susah menanyakan materi yang belum paham dan kurangnya konsentrasi mahasiswa jika dilakukan pembelajaran secara daring (Mastuti, 2020). Terlebih lagi jika dosen yang bersangkutan tidak memiliki keterampilan dalam mengembangkan model pembelajaran yang tepat sesuai dengan situasi saat ini. Hal ini tentu akan memperburuk masalah yang terjadi. Salah satu yang dapat terjadi adalah rasa bosan dikarenakan penggunaan model pembelajaran yang belum tepat. Rasa bosan tersebut dapat mempengaruhi motivasi dan hasil belajar (Nopiyanto \& Raibowo, 2020). Ditambah lagi, salah satu pertanda bahwa seseorang itu sendiri telah menjalani pembelajaran adalah dengan adannya perubahan tingkah laku pada diri orang itu yang mungkin akan disebabkan oleh terjadinya perubahan pada tingkat pengetahuan, 
keterampilan, atau sikap (Raibowo, Nopiyanto, \& Muna, 2019). Apakah makna belajar yang seperti itu dapat tercapai jika pembelajaran dilakukan sepenuhnya secara online? (Rahmatullah, 2019) menyatakan bahwa penggunaan media offline dan online harus digunakan dalam proses pembelajaran di sekolah untuk mengikuti perkembangan zaman. Apabila mengenyampingkan kondisi yang terjadi di tengah wabah saat ini, memang seyogyanya sebuah pembelajaran itu dilakukan secara tatap maka (offline) dan secara daring (online). Namun walaupun demikian, pembelajaran secara daring yang memanfaatkan aplikasi yang sudah dibuat itu dapat mempermudah penyampaian materi yang akan dipalajari secara jarak jauh. Bahkan metode penyampaian informasi secara online ini juga tidak hanya digunakan dalam proses pembelajaran, dalam proses evaluasi atlet juga digunakan, salah satunya aplikasi tes fisik untuk pelatih sekolah sepakbola (Hartati, Victoriand, Yusfi, \& Destriani, 2019). Hanya saja belum diketahui apakah siswa mampu mengikutinya dengan baik proses pembelajaran online tersebut.

Oleh karena itu, terkait dengan hal tersebut maka tujuan dalam melakukan penelitian ini harapannya adalah akan mendapatkan data bentuk perkuliahan daring mahasiswa PJKR Universitas PGRI Semarang sebagai dapak pandemic covid 19, serta demi mendapatkan hasil informasi upaya mahasiswa dalam mengikuti perkuliahan daring mahasiswa PJKR Universitas PGRI Semarang sebagai dampak covid 19 yang sekarang sedang mengguncang dunia, terutama pada dunia pendidikan.

\section{METODE PENELITIAN}

Penelitian ini menggunakan pendekatan deskriptif kuantitatif. Metode yang digunakan dalam penelitian ini dengan menggunakan metode survey dan teknik pengumpulan data menggunakan angket yang diwujudkan dalam bentuk pertanyaan. Waktu penelitian akan dimulai dari bulan April 2020. Tempat penelitian adalah suatu lokasi tertentu yang akan digunakan peneliti untuk melakukan penelitian, dimana terdapat obyek dan subyek yang akan diteliti dalam penelitian. Penelitian ini mengambil subjek penelitian mahasiswa PJKR UPGRIS semua angkatan.

Variabel penelitian ini adalah menganalisis perkuliahan daring mahasiswa PJKR UPGRIS sebagai dampak pandemi covid 19 yang diukur dengan menggunakan angket. Teknik pengumpulan data dengan observasi berdasarkan bila penelitian berkenaan dengan perilaku manusia, proses kerja, gejala-gejala alam dan bila subyek penelitian yang diamati tidak terlalu besar (Sugiyono, 2012). Dalam hal ini yang diberikan angket dalam bentuk google form adalah subyek penelitian (mahasiswa aktif PJKR Universitas PGRI Semarang) dilakukan dengan beberapa cara, baik secara langsung (face to face) maupun melalui telepon (by phone). Kisi-kisi Angket tersebut yang kurang lebih berisi tentang sistem perkuliahan yang cocok untuk mahasiswa PJKR UPGRIS (Zoom, SIP, SPADA, Maupun Google Classroom) serta lamanya durasi waktu perkuliahan secara daring dan untuk mengetahui apakah mahasiswa siap dalam mengikuti perkuliahan secara daring atau tidak.

\section{HASIL PENELITIAN}

Penelitian ini bertujuan untuk mengetahui bentuk dan upaya mahasiswa PJKR UPGRIS dalam pembelajaran daring selama masa pandemi covid pada bulan Maret-April 2020. Sampel yang digunakan sebanyak 477 mahasiswa PJKR UPGRIS. Yang terdiri dari semester 2, 4 dan 6. Berikut hasil deskriptif dari sampel penelitian. 
Tabel 1. Sebaran Sampel Penelitian

\begin{tabular}{cccc}
\hline No & Semester & Jumlah & Prosentase \\
\hline 1 & 2 & 221 & $47.7 \%$ \\
\hline 2 & 4 & 98 & $21.2 \%$ \\
\hline 3 & 6 & 144 & $31.1 \%$ \\
\hline & Total & 477 & $100 \%$ \\
\hline
\end{tabular}

Dari data tabel di atas dapat diketahui bahwa untuk mahasiswa semester 2 dengan jumlah mahasiswa 221 memiliki prosentase sebaran sebanyak 47.7\%. Mahasiswa semester 4 dengan jumlah mahasiswa 98 dengan prosentase 21.2\%. Mahasiswa semester 6 dengan jumlah 144 memiliki prosentase 31.1\%. Dengan demikian bisa diketahui bahwa jumlah keseluruhan mahasiswa yang mengisi sebaran penelitian dengan jumlah total sebanyak 477 mahasiswa.

Tabel 2. Aplikasi yang digunakan

\begin{tabular}{cccc}
\hline No & Aplikasi & Jumlah & Prosentase \\
\hline 1 & Zoom & 282 & $34.7 \%$ \\
\hline 2 & SIP & 334 & $41.2 \%$ \\
\hline 3 & SPADA & 11 & $1.3 \%$ \\
\hline 4 & Google Classroom & 185 & $22.8 \%$ \\
\hline & Total & $\mathbf{8 1 2}$ & $100 \%$ \\
\hline
\end{tabular}

Dari data di atas diketahui jumlah aplikasi yang paling banyak dipakai adalah Zoom 34.7\%, SIP 41.2\%, SPADA 1.3\% dan Google Clasroom 22.8\%. Pemilihan aplikasi ini setiap mahasiswa boleh memilih lebih dari 1 opsi terhadap aplikasi yang sering digunakan. Selanjutnya tabel di bawah akan mendeskrispsikan tentang lama waktu pembelajaran daring.

Tabel 3. Durasi Pembelajaran

\begin{tabular}{cccc}
\hline No & Waktu & Jumlah & Prosentase \\
\hline 1 & Lebih dari 60 menit & 89 & $18.6 \%$ \\
\hline 2 & 30-60 menit & 309 & $64.8 \%$ \\
\hline 3 & Kurang dari 30 menit & 79 & $16.6 \%$ \\
\hline & Total & $\mathbf{4 7 7}$ & $100 \%$ \\
\hline
\end{tabular}

Dari data di atas diketahui durasi pembelajaran daring yang lebih dari 60 menit 18.6\%, 30 menit sampai 60 menit 64.8\% dan di bawah 30 menit 16.6\%. Selanjutnya akan ditampilkan pemahaman mahasiswa terhadap materi pembelajaran daring.

Tabel 4. Pemahaman Terhadap Materi

\begin{tabular}{cccc}
\hline No & Waktu & Jumlah & Prosentase \\
\hline 1 & Mudah dipahami & 340 & $71.2 \%$ \\
\hline 2 & SulitDipahami & 137 & $28.8 \%$ \\
\hline & Total & $\mathbf{4 7 7}$ & $100 \%$ \\
\hline
\end{tabular}

Pada deskripsi di atas pemahaman terhadap materi yaitu: mudah dipahami $71.2 \%$ dan materi susah dipahami 28.8\%. Berikut akan dijabarkan kesiapan mahasiswa dalam proses pembelajaran daring. 
Tabel 5. Kesiapan Mahasiswa

\begin{tabular}{cccc}
\hline No & Waktu & Jumlah & Prosentase \\
\hline 1 & Siap & 100 & $20.9 \%$ \\
\hline 2 & Cukup Siap & 250 & $52.4 \%$ \\
\hline 3 & Kurang Siap & 127 & 26.7 \\
\hline & Total & $\mathbf{4 7 7}$ & $100 \%$ \\
\hline
\end{tabular}

Dari data di atas dapat dijabarkan tingkat kesiapan mahasiswa dalam kategori siap 20.9\%, cukup siap 52.4\%, kurang siap 26.7\%. Berikutnya akan dideskripsikan kendala perkuliahan yang dialami.

Tabel 6. Kendala Pembelajaran

\begin{tabular}{cccc}
\hline No & Waktu & Jumlah & Prosentase \\
\hline 1 & Sinyal & 281 & $58.9 \%$ \\
\hline 2 & Kuota & 121 & $25.3 \%$ \\
\hline 3 & Waktu & 75 & $15.8 \%$ \\
\hline & Total & $\mathbf{4 7 7}$ & $100 \%$ \\
\hline
\end{tabular}

Dari data di atas dapat dideskripsikan kendala terbesar mahasiswa yaitu terkendala sinyal 58.9\%, kuota $25.3 \%$, dan waktu $15.8 \%$. Oleh karena itu bisa kita simpulkan untuk mahasiswa yang mengisi berkaitan dengan angket sebaran terkait dengan kendala perkuliahan daring berjumlah 477 mahasiswa dari program studi Pendidikan Jasmani Kesehatan dan Rekreasi Universitas PGRI Semarang.

\section{PEMBAHASAN}

Mengutip dari hasil penelitian yang dilakukan oleh (Hasanah et al., 2020) tentang analisis aktivitas belajar daring mahasiswa pada pandemi Covid-19. Berdasarkan pengumpulan data hasil penelitian dapat disimpulkan bahwa pelaksanaan aktivitas belajar mahasiswa pada masa tanggap darurat Covid-19 ini berjalan dengan cukup baik. Namun aktivitas belajar daring ini perlu ditingkatkan dengan karena aktivitas belajar merupakan suatu hal yang penting dalam mencapai tujuan belajar. Hal yang mendasari adalah masih ditemukannya hambatan dalam pelaksanaan aktivitas belajar daring pada masa tannggap darurat Covid-19 saat ini. Sedangkan (Hikmat, Hermawan, Aldim, \& Irwandi, 2020) tentang efektivitas pembelajaran daring selama masa pandemi covid-19: sebuah survei online didapatkan hasil dari perhitungan menggunakan metode MAUT terhadap studi kasus efektivitas belajar daring menggunakan aplikasi Zoom dan WhatsApp di Fakultas Ilmu Sosial dan Ilmu Politik UIN Sunan Gunung Djati Bandung menghasilkan pilihan yang lebih objektif dengan penilaian matakuliah teori (0.88) sebagai penilaian tertinggi, disusul mata kuliah teori dan praktikum (0.70), mata kuliah praktikum (0.42) dan mata kuliah di lapangan (0.20). Hal ini berarti bahwa pembelajaran daring hanya efektif untuk mata kuliah teori dan teori dan praktikum saja, sementara untuk mata kuliah praktikum dan mata kuliah lapangan tidak efektif dilakukan secara daring dan lebih efektif menggunakan perkuliahan konvensional dengan tatap muka. Dalam situasi mewabahnya Covid-19 di tanah air, perkuliahan di Perguruan Tinggi memberlakukan system online. Perkuliahan online dimana situasi belajar tidak lagi tatap muka membuat banyak pertanyaan mengenai efektivitas sistem belajar ini, termasuk mahasiswa. Berdasarkan hasil kuesioner terbuka, mayoritas mahasiswa mengatakan sistem online dengan Zoom ini adalah alternatif belajar tatap muka ditengah mewabahnya Covid-19. Oleh karena itu mereka berharap efektivitasnya diharapkan harus setara dengan perkuliahan konvensional (tatap muka). Agar perkuliahan online ini dapat berjalan efektif, pelaksanaannya harus terencana, mulai 
dari kesiapan mahasiswa dan dosen serta bahan ajar. Dalam perkuliahan online, kreativitas dosen sangat diperlukan dalam pembelajaran agar kuliah ini berjalan dengan efektif, sehingga mahasiswa bisa memahami materi yang disampaikan. Selain itu, menurut para mahasiswa, penggunaan alat elektronik seperti handphone dan laptop yang berlebihan dalam pembelajaran, perlu diwaspadai yang sejatinya berdampak pada kesehatan psikis dan fisik.

Covid-19 mempengaruhi seluruh aspek kehidupan manusia, tidak terkecuali dunia pendidikan. Dari hasil data penelitian di atas, pada umumnya pembelajaran daring di lingkungan program studi PJKR sudah berjalan kondusif, walaupun masih tidak seideal apabila perkuliahan dilakukan tatap muka karena beberapa kendala yang dijumpai. Kendala terbesar dari pembelajaran daring adalah sinyal di daerah asal setiap mahasiswa, tidak semua mahasiswa mempunyai tempat tinggal yang mendapatkan akses sinyal internet dengan baik. Kendala ini sedikit teratasi dengan adanya solusi yang diberikan oleh dosen yaitu memberikan rekaman tentang perkuliahan yang sudah dilakukan.

\section{KESIMPULAN}

Dari penelitian yang telah dilakukan dapat disimpulkan: (1) Bentuk perkuliahan yang dilakukan di Program Studi PJKR Universitas PGRI Semarang memanfaatkan platform pembelajaran online seperti Zoom, Google Clasroom, SPADA, maupun SIP. Sedangkan untuk perkuliahan praktek lapangan menggunakan bentuk video dan penugasan, (2) Upaya mahasiswa dalam mengikuti pembelajaran online cukup baik dengan perolehan cukup siap dan persentasenya 52.4\%.

\section{DAFTAR PUSTAKA}

Cendra, R., \& Gazali, N. (2019). Intensitas Olahraga Terhadap Perilaku Sosial. Media Ilmu Keolahragaan Indonesia, 9(1), 13-17.

Dalimunthe, \& Abdillah, R. A. (2015). Strategi dan Implementasi Pelaksanaan Pendidikan Karakter di SMP N 9 Yogyakarta. Jurnal Pendidikan Karakter, 5(1), 102111.

Hartati, Victoriand, A. R., Yusfi, H., \& Destriani. (2019). Pelatihan Penggunaan Aplikasi Tes Fisik Untuk Pelatih Sekolah Sepakbola Di Bawah Binaan KONI Ogan Ilir. Journal Of Sport Education (JOPE), 1(2), 34-36. https://doi.org/10.31258/jo pe.1.2.43-48

Hasanah, A., Lestari, A. S., Rahman, A. Y., \& Daniel, Y. I. (2020). Analisis aktivitas belajar daring mahasiswa pada pandemi Covid-19.

Hikmat, H., Hermawan, E., Aldim, A., \& Irwandi, I. (2020). Efektivitas pembelajaran daring selama masa pandemi Covid-19: Sebuah survey online. LP2M.

Jamaluddin, D., Ratnasih, T., Gunawan, H., \& Paujiah, E. (2020). Pembelajaran daring masa pandemik Covid-19 pada calon guru: hambatan, solusi dan proyeksi. LP2M.

Lee, P.-I., \& Hsueh, P.-R. (2020). Emerging threats from zoonotic coronaviruses-from SARS and MERS to 2019-nCoV. Journal of Microbiology, Immunology and Infection. https://doi.org/10.1016/j.jmii.2020.02.001 
Mastuti, R. (2020). Teaching From Home: Dari Belajar Merdeka Menuju Merdeka Belajar. Medan: Yayasan Kita Menulis.

Nopiyanto, Y. E., \& Raibowo, S. (2020). Penerapan model pembelajaran jigsaw untuk meningkatkan motivasi dan hasil belajar mahasiswa penjas pada mata kuliah filsafat penjas dan olahraga. Journal Of Sport Education (JOPE), 2(2), 61-69. https://doi.org/10.31258/jope.2.2.61-69

Rahmatullah, M. I. (2019). Pengembangan Konsep Pembelajaran Literasi Digital Berbasis Media E-Learning Pada Mata Pelajaran PJOK di SMA Kota Yogyakarta. Journal Of Sport Education (JOPE), 1(2), 56. https://doi.org/10.31258/jope.1.2.5665

Raibowo, S., Nopiyanto, Y. E., \& Muna, M. K. (2019). Pemahaman guru PJOK tentang standar kompetensi profesional. Journal of Sport Education (JOPE), 2(1), 10-15. https://doi.org/10.31258/jope.2.1.10-15

Sugiyono. (2012). Metode Penelitian Kuantitatif Kualitatif dan R\&D. Alfabeta.

Syah, M. (2010). Psikologi Pendidikan dengan pendekatan baru. Bandung: PT. Remaja Rosdakarya.

Zhu, N., Zhang, D., Wang, W., Li, X., Yang, B., Song, J., ... Tan, W. (2020). A Novel Coronavirus from Patients with Pneumonia in China, 2019. The New Engl and Journal of Medicine, 1-7. https://doi.org/10.1056/NEJMoa2 001017 